\title{
PENGARUH KEMAMPUAN INTELEKTUAL DAN ETOS KERJA TERHADAP KINERJA PEGAWAI PADA PT BPRS AMANAH BANGSA PEMATANGSIANTAR
}

\author{
Oleh: \\ Sepri Malik Saragih \\ S1 Manajemen \\ Darwin Lie, Marisi, Julyanthry
}

Abstraksi

Hasil penelitian: 1. Kemampuan intelektual tinggi dan etos kerja cukup tinggi, kinerja pegawai tinggi. 2. Hasil analisis regresi $\hat{Y}=33,312+0,306 X_{1}+0,302 X_{2}$, artinya terdapat pengaruh yang positif antara kemampuan intelektual dan etos kerja terhadap kinerja pegawai. 3. Hasil analisis koefisien korelasi diperoleh nilai $r=0,660$, yang artinya terdapat hubungan yang kuat dan positif antara kemampuan intelektual dan fetos kerja dengan kinerja pegawai. Diperoleh nilai koefisien determinasi $=0,436$, artinya tinggi rendahnya kinerja pegawai sebesar 43,6\% dapat dijelaskan oleh kemampuan intelektual dan etos kerja. 4. Hasil uji hipotesis menyatakan $\mathrm{H}_{\mathrm{O}}$ ditolak, artinya kemampuan intelektual dan etos kerja berpengaruh positif dan signifikan terhadap kinerja pegawai pada Guest PT BPRS Amanah Bangsa Pematangsiantar baik secara simultan maupun parsial.

Adapun saran dari hasil penelitian ini adalah 1. Untuk meningkatkan kemampuan intelektual, perusahaan sebaiknya memberikan peluang untuk pendidikan lebih lanjut dan pelatihan secara rutin untuk menggali potensi pegawai. 2. Untuk meningkatkan etos kerja, pegawai sebaiknya berusaha untuk lebih tulus dan syukur dalam bekerja untuk peningkatan kualitas kerja. 3. Untuk meningkatkan kinerja, perusahaan sebaiknya memberikan kesempatan kepada pegawai untuk berinovasi sehingga menimbulkan kreativitas dalam bekerja.

Kata kunci: Kemampuan Intelektual, Etos Kerja, Kinerja Pegawai.

\section{Abstraction}

The results of this study can be summed summarized as follows: 1. Intellectual Ability is high, ethic of work is high enough and employee performance is high. 2. Regression analysis result is $\hat{\mathrm{Y}}=33,312+0,306 \mathrm{X}_{1}+$ $0,302 \mathrm{X}_{2}$, meaning there is positive influence between intellectual ability and ethic of work on employee performance. 3. The results of the analysis correlations is $r=0,660$ which means there is a moderately high and positive correlation between intellectual ability and ethic of work with employee performance. The level of employee performance can be explained 43,6\% by intellectual ability and ethic of work. 4. Hypothesis test result stated that $\mathrm{H}_{0}$ is rejected, it means intellectual ability and ethic of work have positive and significant influence on employee performance at PT BPRS Amanah Bangsa Pematangsiantar simultaneously and partially.

The suggestions of this research is: 1. To strengthen the intellectual ability, the agency should provide opportunities for further education. 2. To improve ethic of work, employee should try to be more sincere and grateful in working for improving the quality of work. 3. To improve performance, the agency should give opportunity for employees to innovate in order to rise the creativity of work.

\section{Keywords: Intellectual Ability, Ethic of Work and Employee Performance.}

\section{A. PENDAHULUAN}

\section{Latar Belakang Masalah}

PT Bank Pembiayaan Rakyat Syariah Amanah Bangsa Pematangsiantar adalah perusahaan yang bergerak pada pelayanan publik. Semua unsur dalam perusahaan ini harus saling bekerja sama dalam rangka mencapai tujuan perusahaan. Oleh karena itu perusahaan perlu memperhatikan kinerja pegawai sebagai salah satu upaya yang menentukan keberhasilan tujuan-tujuan yang telah ditetapkan.

Tinggi rendahnya kinerja pegawai dapat dilihat dari kemampuan pegawai dalam menyelesaikan tugas. Penilaian kinerja pada PT BPRS Amanah Bangsa Pematangsiantar berdasarkan Surat Edaran Bank Indonesia No. 15/4 INTERN tanggal 26 Februari 2013 yaitu perilaku kerja dan prestasi kerja. Prestasi kerja meliputi keberhasilan, tanggung jawab, pencapaian target, dan tugas. Sedangkan perilaku kerja meliputi pengembangan diri, integritas, membangun kepercayaan, profesionalitas, kerja sama, dan tingkat kehadiran. Berikut ini adalah fenomena kinerja pegawai pada PT BPRS Amanah Bangsa Pematangsiantar.

$$
\text { Tabel } 1
$$

Fenomena Kinerja Pegawai pada PT BPRS Amanah Bangsa Pematangsiantar

\begin{tabular}{|c|c|c|c|c|c|c|}
\hline $\begin{array}{c}\text { Kinerja } \\
\text { Pegawa } \\
\text { i }\end{array}$ & SB & B & CB & TB & $\begin{array}{c}\text { ST } \\
\text { B }\end{array}$ & $\begin{array}{c}\text { Juml } \\
\text { ah }\end{array}$ \\
\hline $\begin{array}{c}\text { Prestasi } \\
\text { Kerja }\end{array}$ & $\begin{array}{c}35 \\
\%\end{array}$ & $\begin{array}{c}45 \\
\%\end{array}$ & $\begin{array}{c}20 \\
\%\end{array}$ & $0 \%$ & $0 \%$ & $100 \%$ \\
\hline $\begin{array}{c}\text { Perilaku } \\
\text { Kerja }\end{array}$ & $\begin{array}{c}25 \\
\%\end{array}$ & $\begin{array}{c}55 \\
\%\end{array}$ & $\begin{array}{c}20 \\
\%\end{array}$ & $0 \%$ & $0 \%$ & $100 \%$ \\
\hline $\begin{array}{c}\text { Rata- } \\
\text { rata }\end{array}$ & $\begin{array}{c}\mathbf{3 0} \\
\text { \% }\end{array}$ & $\begin{array}{c}\mathbf{5 0} \\
\text { \% }\end{array}$ & $\begin{array}{c}\mathbf{2 0} \\
\mathbf{\%}\end{array}$ & $\mathbf{0 \%}$ & $\mathbf{0 \%}$ & $\begin{array}{c}\mathbf{1 0 0} \\
\mathbf{\%}\end{array}$ \\
\hline
\end{tabular}

Sumber: hasil Pra Survey pada PT BPRS Amanah Bangsa Pematangsiantar (Juni, 2017)

Pada tabel 1 di atas, diketahui bahwa kinerja pegawai belum optimal, hal ini dapat dilihat dari adanya dimensi kinerja dengan kategori cukup baik. 
Dari pengamatan penulis, diketahui kinerja pada dimensi prestasi belum optimal, karena pegawai masih kurang mampu mengerjakan tugas secara mandiri. Pada dimensi perilaku kerja, juga belum optimal, karena masih terdapat beberapa pegawai tidak kompeten.

Salah satu faktor yang mempengaruhi kinerja pegawai tersebut adalah kemampuan intelektual pegawai itu sendiri. Adapun dimensi kemampuan intelektual, yaitu kemahiran berhitung, pemahaman verbal, kecepatan konseptual, penalaran induktif, penalaran deduktif, visualisasi ruang, dan ingatan.

Berdasarkan pengamatan penulis, pada fenomena kemampuan intelektual pegawai PT BPRS Amanah Bangsa terjadi pada dimensi pemahaman verbal, dimana terdapat sekitar $35 \%$ pegawai masih mengalami kesalahan dalam pekerjaan padahal mereka sudah sering diberikan arahan oleh pimpinan. Pada dimensi kecepatan konseptual, terdapat sekitar $25 \%$ pegawai masih ragu-ragu melihat kemiripan berkas-berkas calon nasabah. Pada dimensi penalaran deduktif terdapat sekitar $20 \%$ pegawai kurang cakap dalam melakukan tugas. Sedangkan pada dimensi kemahiran berhitung pegawai PT BPRS Amanah Bangsa Pematangsiantar mampu berhitung secara cepat dan tepat. Pada dimensi penalaran induktif, mampu menyelesaikan tugas sesuai dengan urutan logis penyelesaiannya. Pada dimensi visualisasi ruang, mampu menemukan berkas-berkas dengan baik walau posisinya diubah. Serta pada dimensi memori mampu mengingat suatu pekerjaan.

Selain kemampuan intelektual, etos kerja juga dapat mempengaruhi kinerja pegawai. Adapun dimensi etos kerja meliputi kerja adalah rahmat, amanah, panggilan, aktualisasi, ibadah, seni, kehormatan, dan pelayanan. Pada dimensi amanah, panggilan, seni dan kehormatan pegawai PT BPRS Amanah Bangsa sudah optimal.

Fenomena etos kerja pegawai PT BPRS Amanah Bangsa yang belum optimal terjadi pada dimensi kerja sebagai rahmat, sekitar $25 \%$ pegawai masih kurang patuh terhadap aturan kantor. Pada dimensi aktualisasi, sekitar $30 \%$ pegawai terkadang kurang semangat dalam bekerja, terutama ketika memasuki waktu siang dan sore hari. Dan pada dimensi ibadah, sekitar $25 \%$ pegawai masih kurang ikhlas dalam bekerja, hal ini dapat dilihat dari sikap pegawai yang bersungut-sungut ketika rekan kerja meminta bantuan atau mendapat tugas tambahan dari pimpinan.

Berdasarkan hal tersebut di atas, penulis tertarik untuk melakukan penelitian dengan judul: Pengaruh Kemampuan Intelektual dan Etos Kerja terhadap Kinerja Pegawai pada PT BPRS Amanah Bangsa Pematangsiantar.

\section{Rumusan Masalah}

1. Bagaimana gambaran kemampuan intelektual, etos kerja dan kinerja pegawai pada PT BPRS Amanah Bangsa Pematangsiantar.
2. Bagaimana pengaruh kemampuan intelektual dan etos kerja terhadap kinerja pegawai pada PT BPRS Amanah Bangsa Pematangsiantar baik secara simultan maupun parsial.

\section{Tujuan Penelitian}

a. Untuk mengetahui gambaran kemampuan intelektual, etos kerja dan kinerja pegawai pada PT BPRS Amanah Bangsa Pematangsiantar.

b. Untuk mengetahui pengaruh kemampuan intelektual dan etos kerja terhadap kinerja pegawai pada PT BPRS Amanah Bangsa Pematangsiantar baik secara simultan maupun parsial.

\section{Metode Penelitian}

Objek penelitian adalah Yang menjadi objek penelitian dalam hal ini adalah pegawai di PT BPRS Amanah Bangsa Pematangsiantar yang terletak di Jalan Medan Km. 10,5 No.159 Komplek Beringin Graha Permai Pematangsiantar. Populasi adalah seluruh pegawai tetap PT BPRS Amanah Bangsa Pematangsiantar yang berjumlah 26 (dua puluh enam) orang.

Desain penelitian adalah Penelitian Kepustakaan (Library Research) dan Penelitian Lapangan (Field Research). Teknik pengumpulan data berupa Kuesioner, Wawancara dan Dokumentasi. Jenis data yang adalah jenis data kualitatif dan data kuantitatif. Hasil data yang diperoleh dari lapangan akan dianalisis secara deskriptif baik bersifat kualitatif dan kuantitatif.

\section{B. LANDASAN TEORI}

\section{Manajemen Pemasaran}

Menurut Dessler (2006:5), manajemen sumber daya manusia adalah proses memperoleh, melatih, menilai, dan memberikan kompensasi kepada pegawai, memperhatikan hubungan kerja mereka, kesehatan dan keamanan, serta masalah keadilan. Menurut Mathis dan John (2006:3), manajemen sumber daya manusia adalah rancangan sistem-sistem formal dalam sebuah organisasi untuk memastikan penggunaan bakat manusiasecara efektif dan efisien guna mencapai tujuan organisasi. Sedangkan menurut Mondy (2008:4), manajemen sumber daya manusia adalah pemanfaatan para individu untuk mencapai tujuan organisasi.

Berdasarkan beberapa pendapat ahli diatas maka dapat disimpulkan bahwa manajemen sumber daya manusia adalah segala upaya maupun bakat yang ada pada diri seorang individu yng dapat dimanfaatkan untuk kepentingan bersama demi kelangsungan hidup manusia itu sendiri dengan berjalannya tujuan organisasi.

\section{Kemampuan Intelektual}

Menurut Goleman (2002:512), mengatakan bahwa kemampuan intelektual adalah kemampuan untuk mengenali perasaan kita sendiri dan perasaan orang lain, kemampuan memotivasi diri sendiri dan kemampuan mengelola emosi dengan baik pada diri 
sendiridan dalam hubungan dengan orang lain. Menurut Robbins dan Timothy (2009:57), kemampuan intelektual adalah kemampuan mental yang diperlukan untuk menjalankan kegiatan mental. Kemampuan intelektual akan menjadikan individu mempunyai kompetensi untuk dapat melaksanakan tugas-tugasnya dengan tanpa keraguan sehingga menghasilkan kinerja yang lebih baik. Sedangkan menurut Sutrisno (2011:272), kecerdasan intelektual merupakan kemampuan yang diperlukan untuk menjalankan kegiatan mental.

Berdasarkan beberapa pendapat ahli di diatas, penulis mengambil kesimpulan bahwa kemampuan intelektual adalah kapasitas umum dari kesadaran individu untuk berfikir, menyesuaikan diri, mengelola emosi, dan memecahkan masalah secara bijaksana serta cepat dan tepat.

\section{Etos Kerja}

Menurut Anoraga (2009:282), etos kerja merupakan suatu pandangan dan sikap suatu bangsa atau umat terhadap kerja. Bila orang-orang dalam komunitas memandang bekerja sebagai suatu hal mulai bagi eksistensi manusia, maka etos kerjanya akan cenderung tinggi. Menurut Tasmara (2002:32), etos kerja adalah segala ilmu kebaikan dan keburukan yang ada di dalam diri manusia yang merupakan pertimbangan perbuatan dalam melakukan pekerjaan yang akan tampak dalam sikap dan tingkah lakunya. Sedangkan menurut Sinamo (2005:151), etos kerja didefinisikan sebagai sekumpulan cara bekerja positif yang berdasar pada keyakinan fundamental dan disertai komitmen total pada paradigma kerja yang integral.

Berdasarkan beberapa pendapat diatas, penulis menyimpulkan bahwa etos kerja merupakan seperangkat sikap atau pandangan mendasar yang dipegang pegawai untuk menilai bekerja sebagai suatu hal yang positif bagi peningkatan kualitas kehidupan, sehingga mempengaruhi perilaku kerjanya dalam organisasi.

\section{Kinerja Pegawai}

Menurut Rivai (2005:14), kinerja pegawai merupakan hasil atau tingkat keberhasilan individu pekerja atau keseluruhan dalam waktu tertentu di dalam melaksanakan tugas dibandingkan dengan berbagai kemungkinan, seperti standar hasil kerja, target atau sasaran dan juga kriteria yang telah ditentukan terlebih dahulu dan telah disepakati bersama. Menurut Mathis dan John (2006:13) kinerja dapat didefinisikan suatu hasil kerja yang dicapai seseorang dalam melaksanakan tugas-tugas yang dipercayakan kepadanya yang disarankan atas pengalaman, kecakapan, kesungguhan, serta waktu. Sedangkan menurut Mangkunegara (2004:1), kinerja adalah pencapaian hasil kerja oleh seorang pegawai secara kualitas dan kuantitas yang dinilai dalam melaksanakan tugas dan tanggung jawab yang diberikan kepadanya.

Berdasarkan uraian diatas, penulis dapat menyimpulkan bahwa kinerja merupakan prestasi kerja atau hasil yang dicapai oleh seorang pegawai dalam melaksanakan tugasnya dengan tanggung jawab yang diberikan kepadanya.

\section{PEMBAHASAN \\ 1. Analisa}

\section{a. Deskriptif Kualitatif}

Analisis deskriptif kuantitatif dimaksudkan untuk mendapatkan gambaran atau deskripsi mengenai pengaruh kemampuan dan etos kerja terhadap kinerja pegawai pada PT BPRS Amanah Bangsa Pematangsiantar. Setelah pengujian data, maka langkah selanjutnya peneliti melakukan pengkajian analisis kualitatif sebagai gambaran fenomena dari variabel penelitian pada saat sekarang ini. Adapun penetapan kriteria nilai rata-rata jawaban dari responden tersebut dimasukkan ke dalam kelaskelas interval dimana penentuan intervalnya memakai rumus sebagai berikut:

$$
\begin{aligned}
\text { Interval Kelas } & =\frac{\text { Nilai Tertinggi }- \text { Nilai Terendah }}{\text { Jumlah Kelas }} \\
& =5-\underline{5} \\
& =\frac{4}{5} \quad 0,8
\end{aligned}
$$

Dari rumus diatas dapat diperoleh interval kelas 0,8 sehingga berlaku ketentuan kategori dengan hasil berikut:

Tabel 2

Nilai Interval dan Kategori Jawaban Responden.

\begin{tabular}{|c|c|c|c|}
\hline \multirow{2}{*}{$\begin{array}{c}\text { Nilai } \\
\text { Interval }\end{array}$} & \multicolumn{3}{|c|}{ Kategori } \\
\cline { 2 - 4 } & $\begin{array}{c}\text { Kemampuan } \\
\text { Intelektual }\end{array}$ & $\begin{array}{c}\text { Etos } \\
\text { Kerja }\end{array}$ & $\begin{array}{c}\text { Kinerja } \\
\text { Pegawai }\end{array}$ \\
\hline $\begin{array}{c}1,00- \\
1,80\end{array}$ & $\begin{array}{c}\text { Sangat } \\
\text { Rendah }\end{array}$ & $\begin{array}{c}\text { Sangat } \\
\text { Rendah }\end{array}$ & $\begin{array}{c}\text { Sangat } \\
\text { Rendah }\end{array}$ \\
\hline $\begin{array}{c}1,81- \\
2,60\end{array}$ & Rendah & Rendah & Rendah \\
\hline $\begin{array}{c}2,61- \\
3,40\end{array}$ & Cukup & $\begin{array}{c}\text { Cukup } \\
\text { Tinggi }\end{array}$ & $\begin{array}{c}\text { Cukup } \\
\text { Tinggi }\end{array}$ \\
\hline $\begin{array}{c}3,41- \\
4,20\end{array}$ & Tinggi \\
\hline $\begin{array}{c}\text { Tingi } \\
5,00\end{array}$ & Tinggi & Tinggi \\
\hline
\end{tabular}

Sumber : hasil pengolahan data (2017)

\section{1) Gambaran Harga pada Guest House Humanitas Pematangsiantar}

Dari hasil analisa, dimensi kemahiran berhitung pada indikator tingkat kemampuan pegawai dalam berhitung secara tepat berada pada rata-rata 3,76 dengan kriteria jawaban tinggi. Hal ini disebabkan pegawai yang memiliki kemampuan berhitung dengan baik dan didukung dengan latar belakang pendidikan pegawai. Pada indikator kemampuan pegawai dalam berhitung dengan cepat berada pada rata-rata 3,73 dengan kriteria jawaban tinggi. Hal ini juga dilihat dari kecepatan pegawai dalam menyelesaikan tugas. Selanjutnya pada indikator tingkat kemampuan pegawai dalam mengerjakan tugas berada pada rata-rata 3,96 dengan 
kriteria jawaban tinggi.Hal ini disebabkan pegawai mampu dalam menyelesaikan pekerjaan dengan baik dan tepat waktu.

Pada dimensi pemahaman verbal, untuk indikator kemampuan pegawai dalam memahami apa yang dibaca berada pada rata-rata 3,50 dengan kriteria jawaban tinggi. Hal ini disebabkan hampir semua pegawai dapat membaca dan memahami apa yang dibacanya, hal ini dapat dilihat dari pekerjaan yang dapat diselesaikan dengan baik ketika membaca berkas-berkas nasabah. Pada indikator kemampuan pegawai dalam memahami apa yang didengar berada pada rata-rata 3,46 dengan kriteria jawaban tinggi. Hal ini disebabkan pegawai mampu mendengar dengan baik sehingga memahami apa yang didengarnya dan menghasilkan pekerjaan yang baik. Selanjutnya pada indikator tingkat kemampuan pegawai dalam menyampaikan pendapat berada pada rata-rata 3,84 dengan kriteria jawaban tinggi. Hal ini disebabkan sebagian besar pegawai mampu menyampaikan pendapat pada saat acara resmi ataupun non resmi untuk kemajuan perusahaan.

Pada dimensi kecepatan konseptual, untuk indikator kemampuan pegawai dalam mengenali kemiripan berkas berada pada rata-rata 3,42 dengan kriteria tinggi.Hal ini disebabkan sebagian besar pegawai mampu menyelesaikan tugas dengan baik sekalipun berkas memiliki perbedaan.Pada indikator kemampuan dalam menalar berada pada rata-rata 3,30 dengan kriteria jawaban cukup tinggi. Hal ini disebabkan pegawai memiliki kemampuan menalar yang baik dalam menyelesaikan tugasnya. Pada indikator kemampuan pegawai mengidentifikasi perbedaan suatu permasalahan berada pada rata-rata 3,11 dengan kriteria jawaban cukup tinggi. Hal ini karena pegawai mampu mengidentifikasi perbedaan suatu permasalahan dengan cukup baik.

Pada dimensi penalaran induktif, untuk indikator kemampuan pegawai dalam mengenali pekerjaan berada pada rata-rata 3,88 dengan kriteria tinggi. Hal ini disebabkan kemampuan yang pegawai dalam mengenali setiap pekerjaan dengan baik.Pada indikator menyelesaikan masalah berdasarkan urutan logisnya berada pada rata-rata 3,65 dengan kriteria jawaban tinggi. Hal ini disebabkan pegawai memiliki kemampuan yang baik dalam menyelesaikan tugas berdasarkan urutan logisnya. Selanjutnya pada indikator memecahkan pekerjaan yang sulit berada pada rata-rata 3,73 dengan kriteria jawaban tinggi. Hal ini disebabkan kemampuan pegawai dalam menyelesaiakan pekerjaan yang sulit dengan baik.

Pada dimensi penalaran deduktif, untuk indikator kelogisan dalam menilai suatu argumen yang diberikan berada pada rata-rata 3,61 dengan kriteria jawaban tinggi. Hal ini terlihat dari kemampuan pegawai menggunakan logika ketika menilai argumen yang diterimanya. Untuk indikator kecakapan dalam menjalankan tugas berada pada rata-rata 3,65 dengan kriteria jawaban tinggi. Hal ini disebabkan kemampuan pegawai dalam mengerjakan tugas dengan baik dan benar. Selanjutnya pada indikator ketelitian dalam bekerja berada pada ratarata 3,30 dengan kriteria jawaban cukup tinggi. Hal ini disebabkan masih terdapat sebagian pegawai yang kurang teliti dalam bekerja.

Pada dimensi visualisasi ruang, pada indikator kemampuan memvisualisasi penyelesaian masalah berada pada rata-rata 3,73 dengan kriteria jawaban tinggi. Hal ini disebabkan tidak semua pegawai mampu memvisualisasi penyelesaian masalah dengan baik. Pada indikator membayangkan posisi benda seandainya posisi letaknya diubah berada pada rata-rata 3,80 dengan kriteria jawaban tinggi. Hal ini disebabkan karena kemampuan pegawai membayangkan posisi benda keika posisi letaknya telah diubah. Pada indikator kemampuan mengerjakan tugas dengan ruangan yang diubah berada pada rata-rata 3,80 dengan kriteria jawaban tinggi. Hal ini disebabkan kemampuan pegawai yang baik dalammenyelesaikan tugas dengan ruang kerja yang diubah.

Pada dimensi ingatan, untuk indikator kemampuan pegawai mengingat pengalaman kerja sebagai pembelajaran berada pada rata-rata 3,76 dengan kriteria jawaban tinggi, hal ini terlihat dari pegawai yang mampu mengingat pengalaman kerja sehingga tidak melakukan kesalahan yang sama ketika dihadapkan pada pekerjaan yang sama. Ingatan pegawai terhadap suatu pekerjaan yang sudah lama tidak dikerjakan berada pada rata-rata 3,73 dengan kriteria jawaban tinggi. Hal ini disebabkan pegawai mampu mengenang kembali pengalaman dalam bekerja dan tetap mengingat pekerjaan sekalipun sudah lama tidak dikerjakan. Pada indikator mengingat suatu pekerjaan berada pada rata-rata 4,03 dengan kriteria jawaban tinggi. Hal ini disebabkan tuntutan pekerjaan untuk mampu mengingat pekerjaan agar pekerjaan tidak terbengkalai.

Secara keseluruhan dapat dilihat bahwa nilai rata-rata kemampuan intelektual yang dimiliki setiap pegawai yang diberikan kepada responden berada pada nilai 3,65 dengan kriteria jawaban tinggi. Kemudian nilai rata-rata tertinggi sebesar 4,03 dengan kriteria jawaban tinggi pada pada dimensi ingatan dengan indikator ingatan pegawai dalam mengingat suatu pekerjaan. Sedangkan nilai rata-rata terendah sebesar 3,11 pada dimensi kecepatan konseptual dengan indikator kemampuan pegawai mengidentifikasi perbedaan suatu masalah.

\section{2) Gambaran Etos Kerja pada PT BPRS Amanah Bangsa Pematangsiantar}

Dari hasil analisa, untuk dimensi kerja adalah rahmat pada indikator ketulusan dalam bekerja berada pada rata-rata 3,30dengan kriteria jawaban cukup tinggi. Hal ini disebabkan karena masih terdapat pegawaiyang kurang tulus melakukan pekerjaannya. Pada indikator rasa syukur pegawai dalam bekerja berada pada rata-rata 3,26 dengan kriteria jawaban cukup tinggi. Hal ini terjadi karena masih terdapat pegawai yang mengeluh atas pekerjaannya. Pada indikator kepatuhan dalam bekerja, berada pada rata-rata 3,19 dengan kriteria jawaban cukup tinggi. Hal initerjadi karena masih banyak pegawai kurang patuh dalam bekerja. 
Pada dimensi kerja adalah amanah,pada indikator komitmen dalam melakukan pekerjaan berada pada rata-rata 3,50 dengan kriteria jawaban tinggi. Hal ini disebabkan karena pegawai memiliki komitmen yang tinggi untuk bekerja dengan baik. Pada indikator tanggung jawab dalam melakukan pekerjaan berada pada rata-rata 3,61 dengan kriteria jawaban tinggi. Hal ini karena pegawai memiliki tanggung jawab yang tinggi dalam bekerja. Pada indikator menjalankan pekerjaan dengan benar berada pada rata-rata 3,53 dengan kriteria jawaban tinggi. Hal ini disebabkan pegawai melakukan pekerjaan sesuai dengan prosedur kerja.

Selanjutnya pada dimensi kerja adalah panggilan dengan indikator ketuntasan pekerjaan pegawai berada pada rata-rata 3,50 dengan kriteria jawaban tinggi. Hal ini terjadi karena pegawai mau menerima dan menyelesaikan tugas dengan tuntas. Pada indikator integritas dalam mengerjakan tugas diperleh nilai rata-rata 3,42 dengan kriteria jawaban sangat tinggi. Hal ini karena pegawai memiliki panggilan untuk bekerja dengan penuh integritas. Pada indikator bekerja dengan sepenuh hati berada pada rata-rata 3,38 dengan kriteria jawaban tinggi. Hal ini terjadi karena pegawai memiliki panggilan untuk bekerja segenap hati.

Pada dimensi kerja adalah aktualisasi dengan indikator keinginan pegawai untuk bekerja keras berada pada rata-rata 3,30 dengan kriteria jawaban cukup tinggi.Hal ini karena masih ditemukannya pegawai yang tidak mau bekerja keras dalam bekerja. Hal ini terlihat dari sikap pegawai yang bekerja hanya sesuai standar tanpa mau meningkatkan kualitas pekerjaannya. Pada indikator semangat pegawai dalam bekerja berada pada ratarata 3,26 dengan kriteria jawaban cukup tinggi. Hal ini terlihat dari sikap pegawai yang lebih memilih bermain wifi dari pada menyelesaikan pekerjaannya ketika sore hari. Pada indikator upaya pegawai untuk mendapatkan prestasi dalam bekerja diperoleh nilai rata-rata 3,07 dengan kriteria cukup tinggi. Hal initerjadi karena pegawai kurang memiliki dorongan untuk berprestasi dalam bekerja.

Pada dimensi kerja adalah ibadah dengan indikator keseriusan pegawai dalam bekerja diperoleh nilai rata-rata 3,23 dengan kriteria jawaban cukup tinggi. Hal ini terjadi karena masih terdapat pegawai tidakmemiliki keyakinan yang kuat melayani nasabah dengan serius sebagai ibadah. Pada indikator kecintaan pegawai terhadap pekerjaan diperoleh nilai rata-rata 3,19 dengan kriteria jawaban cukup tinggi. Hal ini dapat terlihat dari inisiatif pegawai yang kurang baik ketika bekerja. Pada indikator keikhlasan pegawai dalam bekerja diperoleh nilai rata-rata 3,15 dengan kriteria jawaban cukuptinggi. Hal ini terlihat dari sikap kurang baik pegawai ketika diminta melakukan pekerjaan lebih atau diminta bantuan oleh ekan kerja.

Pada dimensi kerja adalah seni dengan indikator kecerdasan pegawai dalam bekerja diperoleh nilai rata-rata 3,46 dengan kriteria jawaban tinggi. Hal ini terjadi karena pegawai memiliki tingkat pendidikan yang baik untuk bekerja dengan cerdas. Pada indikator kreativitas pegawai dalam bekerja diperoleh nilai rata-rata 3,42 dengan kriteria jawaban tinggi. Hal ini terjadi karena pegawai diberikan kebebasan dalam metode kerja asal sesuai standar perusahaan. Pada indikator pegawai menjadikan pekerjaan sebagai sarana mewujudkan cita-cita diperoleh nilai rata-rata 3,42 dengan kriteria jawaban tinggi. hal ini terjadi karena pegawai untuk menjadikan pekerjaannya sebagai saranamewujudkan cita-cita.

Pada dimensi kerja adalah kehormatan dengan indikator ketekunan pegawai dalam bekerja diperoleh nilai rata-rata 3,38 dengan kriteria jawaban cukup tinggi. Hal ini terjadi karena pegawai tidak tekun dalam bekerja. Pada indikator bekerja dengan penuh keunggulan diperoleh nilai rata-rata 3,34 dengan kriteria jawaban cukup tinggi. Hal ini terjadi karena pegawai cukup memiliki sikap positif untuk bekerja dengan penuh keunggulan. Pada indikator upaya pegawai menjadikan pekerjaan sebagai sarana meningkatkan wibawa diperoleh nilai rata-rata 3,38 dengan kriteria jawaban cukup tinggi. Hal ini dikarenakan pegawai merasa bangga dengan pekerjaannya dan menganggapsebagai sarana meningkatkan wibawanya.

Pada dimensi kerja adalah pelayanan dengan indikator tingkat kemauan pegawai bekerja dengan paripurna diperoleh nilai rata-rata 3,57 dengan kriteria jawaban tinggi. Hal ini terjadi karena setiap pegawai mau bekerja sama atau bekerja paripurna dalam menyelesaikan pekerjaannya untuk kemajuan instansi. Pada indikator kemauan pegawai untuk bekerja dengan sepenuh hati diperoleh nilai rata-rata 3,50 dengan kriteria jawaban tinggi. Hal ini terjadi karena pegawai memiliki kemauan bekerja dengan sepenuh hati yang tinggi. Pada indikator sikap positif pegawai dalam menilai bekerja sebagai bentuk pelayanan diperoleh nilai rata-rata 3,65dengan kriteria jawaban tinggi. Hal ini karena pegawai memiliki sikap positif dalam memandang pekerjaan sebagai bentuk pelayanan.

Secara keseluruhan dapat dilihat bahwa nilai rata-rata etos kerja yang dimiliki setiap pegawai yang diberikan kepada responden berada pada nilai 3,37 dengan kriteria jawaban cukup tinggi. Kemudian nilai rata-rata tertinggi sebesar 3,65 dengan kriteria jawaban tinggi pada dimensi kerja adalah pelayanan dengan indikator bekerja sebagai bentuk pelayanan. Sedangkan nilai rata-rata terendah sebesar 3,15 dengan dimensi kerja adalah ibadah dengan indikator keikhlasan kerja.

\section{3) Gambaran Kinerja Pegawai pada PT BPRS} Amanah Bangsa Pematangsiantar

Dari hasil analisa, dimensi pretasi kerja pada tingkat kecepatan terdapat pada nilai rata-rata 4,11 dengan kriteria jawaban tinggi. Hal ini disebabkan karena karyawan mampu bekerja dengan cepat. Pada indikator penghargaan terdapat pada nilai rata-rata 4,07 dengan kriteria jawaban tinggi. Hal ini dikarenakan apabila karyawan berprestasi akan mendapat penghargaan sebagai motivasi. Pada indikator tanggungjawab terhadap tugas terdapat 
nilai rata-rata 4,30 dengan kriteria jawaban sangat tinggi. Hal ini disebabkan karena karyawan bertanggungjawab terhadap tugas yang dibebankan kepadanya.

Pada indikator tanggungjawab terhadap keputusan memperoleh nilai rata-rata 4,26 dengan kriteria jawaban sangat tinggi. Hal ini dikarenakan karyawan bertanggungjawab terhadap keputusan yang dipilih.Pada indikator hasil yang di dapat dalam menyelesaikan pekerjaan sesuai dengan target pada tingkat yang memuaskan berada pada rata-rata 4,23 dengan kriteria jawaban sangat tinggi.Hal ini karena karyawan antusias untuk mencapai target kerja yang baik, sehingga pekerjaan berlebih tidak mempengaruhi sikap karyawan dalam bekerja.

Pada indikator mencapai target sesuai dengan waktu yang ditentukan berada pada nilai rata-rata 4,50 dengan kriteria jawaban sangat tinggi. Hal ini terjadi karena karyawan dapat bekerja dengan tepat waktu sesuai dengan waktu yang telah ditentukan. Indikator melaksanakan tugas sesuai dengan jabatan yang dimiliki berada pada nilai ratarata 4,23 dengan kriteria jawaban sangat tinggi. Hal ini karena setiap karyawan dituntut untuk menyelesaikan tugas dengan baik. Pada indikator menyelesaikan tugas dengan mandiri memperoleh nilai rata-rata 3,38 dengan kriteria jawaban cukup tinggi. Hal ini dikarenakan karyawan belum terbiasa menyelesaikan tugas dengan mandiri.

Pada dimensi perilaku kerja pada indikator menyelesaikan pekerjaan sesuai dengan target yang telah ditentukan berada pada niai rata-rata 4,07 dengan kriteria jawaban tinggi. hal ini disebabkan karena karyawan mampu menyelesaikan pekerjaan sesuai dengan target yang telah ditentukan. Selanjutnya indikator kreativitas untuk menyelesaikan tugas agar dapat hasil yang baik berada pada nilai rata-rata 4,03 dengan kriteria jawaban tinggi. Hal ini disebabkan karena karyawan dapat meyelesaikan tugas dengan baik. Pada indikator bertindak sesuai dengan aturan berada pada nilai rata-rata 3,69 dengan kriteria jawaban tinggi. Hal ini disebabkan karena karyawan taat dengan peraturan yang telah ditetapkan.

Pada indikator memegang teguh prinsipprinsip etika dalam bekerja berada pada nilai ratarata 4,15 dengan kriteria jawaban tinggi. Hal ini disebabkan karena karyawan memegang teguh prinsip-prinsip etika dan kesopanan yang baik.Pada indikator membuktikan kompetensi berada pada nilai rata-rata 4,23 dengan kriteria jawaban tinggi.Hal ini disebabkan karena karyawan mampu menyelesaikan pekerjaan maupun pekerjaan di bidang barunya karena adanya bimbingan dan arahan dari pimpinan. Pada indikator berbagi informasi tanpa ada yang disembunyikan berada pada nilai rata-rata 4,19 dengan kriteria jawaban tinggi. Hal ini karena karyawan saling berbagi informasi tanpa ada yang disembunyikan.

Pada indikator bekerja lebih baik dari standar berada pada nilai rata-rata 4,11 dengan kriteria jawaban tinggi. Hal ini karena karyawan mampu bekerja dengan lebih baik dari standar yang telah ditentukan. Selanjutnya, pada indikator memahami tugas berada pada nilai rata-rata 4,19 dengan kriteria jawaban tinggi. Hal ini karena karyawan memahami dan bertanggung jawab sebagai karyawan bank. Pada indikator dapat bekerja dengan baik berada pada nilai rata-rata 4,03 dengan kriteria jawaban tinggi. Hal ini karena karyawan mampu bekerja dengan tim agar mendapat hasil yang diharapkan.

Pada indikator memberikan kontribusi yang baik berada pada nilai rata-rata 3,96 dengan kriteria jawaban tinggi. Hal ini karena karyawan dapat bekerja dengan baik dalam tim. Selanjutnya pada indikator tingkat kehadiran berada pada nilai ratarata 3,76 dengan kriteria jawaban tinggi. Hal ini karena karyawan selalu hadir dan jarang cuti kecuali ada urusan yang sangat penting. Pada indikator ketepatan waktuatas kehadiran berada pada nilai rata-rata 3,73 dengan kriteria jawaban tinggi. Hal ini karena karyawan selalu hadir tepat waktu dikantor.

Secara keseluruhan kinerja karyawan memiliki nilai rata-rata 4,06 yang berkriteria tinggi. Nilai rata-rata kinerja karyawan tertinggi padadimensi prestasi kerja dengan indikatormencapai target sesuai dengan waktu yang ditentukan memiliki nilai rata-rata 4,50 yang berkriteria sangat tinggi. Dan nilai rata-rata kinerja karyawan terendah pada dimensi prestasi kerja indikator terbiasa menyelesaikan tugas dengan mandiri memiliki nilai rata-rata 3,38 yang berkriteria cukup tinggi.

\section{b. Deskriptif Kuantitatif}

\section{1) Regresi Linear Berganda}

Penelitian ini memiliki tujuan untuk menganalisis pengaruh kemampuan intelektual dan etoa kerja terhadap kinerja pegawai. Analisis data dalam penelitian ini menggunakan analisis regresi linier berganda. Analisis regresi linier berganda digunakan untuk mengetahui pengaruh variabel bebas $(\mathrm{X})$ dan variabel terikat $(\mathrm{Y})$, dimana $\mathrm{X}$ adalah kemampuan intelektual, etos kerja, dan $\mathrm{Y}$ adalah kepuasan pelanggan. Maka dilakukan perhitungan menggunakan program aplikasi SPSS versi 21 dengan hasil hitung regresi sebagai berikut: Tabel 3

Hasil Regresi Linier Berganda Coefficients $^{\mathrm{a}}$

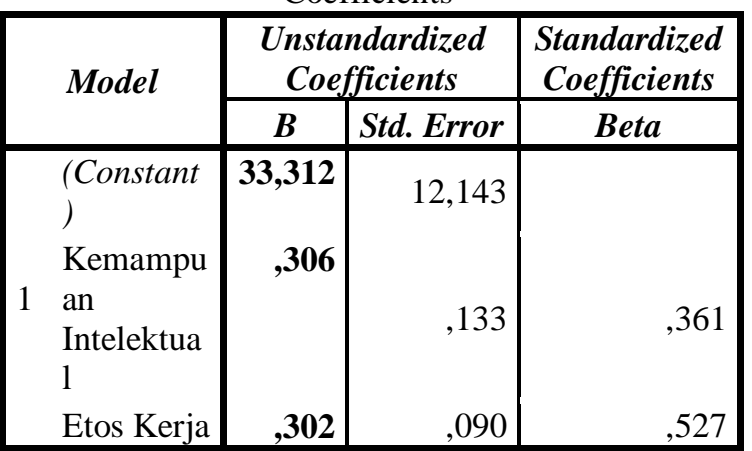

a. Dependent Variable: Kepuasan pelanggan

Berdasarkan hasil pengolahan data pada tabel 3 di atas diperoleh model persamaan 
$\hat{\mathrm{Y}}=33,312+0,306 \mathrm{X}_{1}+0,302 \mathrm{X}_{2}$, artinya terdapat pengaruh yang positif antara variabel kemampuan intelektual $\left(\mathrm{X}_{1}\right)$ dan variabel etos kerja $\left(\mathrm{X}_{2}\right)$ terhadap kinerja pegawai (Y) pada PT BPRS Amanah Bangsa Pematangsiantar.

\section{2) Koefisien Korelasi dan Koefisien Determinasi}

Hasil koefisien korelasi dan koefisien determinasi dapat dilihat pada tabel berikut : Tabel 4

Hasil Koefisien Korelasi dan Determinasi

\begin{tabular}{|l|c|r|r|r|}
\hline Model & $\boldsymbol{R}$ & $\begin{array}{c}\boldsymbol{R} \\
\text { Squar } \\
\boldsymbol{e}\end{array}$ & $\begin{array}{c}\text { Adjusted } \boldsymbol{R} \\
\text { Square }\end{array}$ & $\begin{array}{c}\text { Std. Error } \\
\text { of the } \\
\text { Estimate }\end{array}$ \\
\hline 1 & $\mathbf{6 6 0}^{\mathrm{a}}$ &, $\mathbf{4 3 6}$ &, 387 & $\mathbf{4 , 3 9 5 2 7}$ \\
\hline
\end{tabular}

a. Predictors: (Constant), Harga, Failitas

b. Dependent Variable: Kepuasan Pelanggan

Berdasarkan tabel 4 diperoleh nilai $r=$ 0,660 yang artinya terdapat hubungan yang kuat dan positif antara kemampuan intelektual dan etos kerja terhadap kinerja pegawai pada PT BPRS Amanah Bangsa Pematangsiantar. Selanjutnya diperoleh koefisien determinasi $\mathrm{R}$ square 0,436 artinya tinggi rendahnya kepuasan pelanggan sebesar 43,6\% dapat dijelaskan oleh kemampuan intelektual dan etos kerja. Sedangkan sisanya sebesar 33\% dipengaruhi oleh faktor-faktor lain seperti motivasi, disiplin kerja, budaya organisasi, lingkungan kerja dan faktor lain yang tidak diteliti dalam penelitian ini.

\section{3) Uji Hipotesis}

\section{a) Uji Simultan (Uji F)}

Uji $\mathrm{F}$ digunakan untuk mengetahui apakah variabel bebas (harga dan fasilitas) berpengaruh terhadap variabel terikat (kepuasan pelanggan) secara bersama-sama atau simultan. Pengujian ini dilakukan untuk membandingkan antara $F_{\text {hitung }}$ dan $F_{\text {tabel }}$ pada taraf signifikansi sebesar $5 \%$ atau $\alpha=0,05$ dengan menggunakan program aplikasi SPSS, dapat dilihat dari tabel berikut:

Tabel 5

Hasil Uji Simultan (Uji F)

Berdasarkan tabel 5 di atas, diperoleh nilai $F_{\text {hitung }}$ sebesar $8,883>F_{\text {tabel }}$ dengan $(0,05 ; 2$ vs 192) sebesar 3,42 atau dengan taraf signifikan $0,000 \leq \alpha$ 0,05 , maka $\mathrm{H}_{0}$ ditolak artinya kemampuan intelektual dan etos kerja berpengaruh positif dan signifikan terhadap kinerja pegawai pada Guest House Humanitas Pematangsiantar.

\section{b) Uji Parsial (Uji t)}

Untuk menghasilkan suatu kesimpulan yang valid, maka harus dilakukan uji hipotesis (uji t). Dari hasil perhitungan koefisien korelasi diketahui bahwa kemampuan intelektual, etos kerja dan kinerja pegawai berhubungan, untuk menguji kebenarannya maka dilakukan pengujian hipotesis dengan menggunakan program SPSS, yaitu:

$$
\text { Tabel } 6
$$

Perkiraan Nilai thitung
Coefficients $^{\mathrm{a}}$

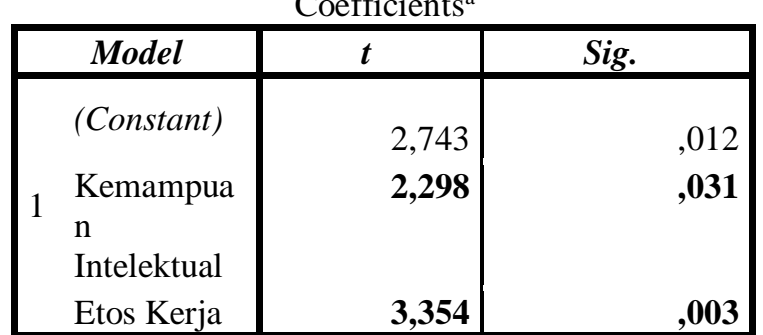

a. Dependent Variable: Kepuasan Pelanggan

Berdasarkan tabel 6 diperoleh nilai thitung pada variabel kemampuan intelektual $\left(\mathrm{X}_{1}\right)$ sebesar $2,298>t_{\text {tabel }}$ dengan $\mathrm{df}=\mathrm{n}-\mathrm{k}-1 \quad(195-2-1=192)$ sebesar 2,068 atau dengan taraf signifikan $0,031 \leq \alpha$ 0,05 , maka $\mathrm{H}_{0}$ ditolak, artinya kemampuan intelektual berpengaruh positif dan signifikan terhadap kinerja pegawai pada PT BPRS Amanah Bangsa Pematangsiantar secara parsial.

Sedangkan thitung pada variabel etos kerja $\left(\mathrm{X}_{2}\right)$ sebesar $3,354>$ dari tabel dengan $\mathrm{df}=\mathrm{n}-\mathrm{k}-1 \quad(195-2-1=192)$ sebesar 2,068 atau dengan taraf signifikan $0,003 \leq \alpha 0,05$, maka $\mathrm{H}_{0}$ ditolak, artinya etos kerja berpengaruh positif dan signifikan terhadap kinerja pegawai pada PT BPRS Amanah Bangsa Pematangsiantar secara parsial.

\section{Evaluasi}

a. Kemampuan Intelektual pada PT BPRS Amanah Bangsa Pematangsiantar

Kemampuan intelektual sangat mempengaruhi kualitas dan kuantitas para pegawai dalam bekerja. Kemampuan intelektual pada PT BPRS Amanah Bangsa Pematangsiantar dapat dikatakan tinggi, hal ini dapat dilihat dari hasil kuesioner yang dibagikan kepada responden yang secara keseluruhan diperoleh dengan nilai rata-rata 3,65 dengan kriteria jawaban tinggi

Namun ada beberapa aspek yang dinilai tinggi tapi masih ada yang dibawah rata-rata indikator lain, yang pertama yaitu pada dimensi pemahaman verbal dengan indikator memahami apa yang dibaca diperoleh nilai rata-rata 3,50 dengan kriteria jawaban tinggi, cara meningkatkannya adalah pegawai lebih sering bertanya kepada

\section{ANOVA ${ }^{\mathrm{a}}$}

\begin{tabular}{|l|r|r|r|r|r|}
\hline Model & $\begin{array}{c}\text { Sum of } \\
\text { Squares }\end{array}$ & Df & $\begin{array}{l}\text { Mean } \\
\text { Squar } \\
\boldsymbol{e}\end{array}$ & F & Sig. \\
\hline Regressi & 343,216 & 2 & 171,60 & $\mathbf{8 , 8 8}$ & $\mathbf{, 0 0 1}$ \\
$\quad$ on & & 8 & $\mathbf{3}$ & b \\
Residual & 444,322 & 23 & 19,318 & & \\
$\quad$ Total & 787,538 & 25 & & & \\
\hline
\end{tabular}

a. Dependent Variable: Kinerja Pegawai

b. Predictors: (Constant), Etos Kerja, Kemampuan Intelektual

pimpinan atau sesama rekan kerja. Pada indikator memahami apa yang didengar diperoleh nilai ratarata 3,46 dengan kriteria jawaban tinggi, cara meningkatkannya adalah pegawai jangan sungkan bertanya tentang apa yang tidak dipahami. 
Pada dimensi kecepatan konseptual dengan indikator kemampuan pegawai mengenali kemiripan berkas diperoleh nilai rata-rata 3,42 dengan kriteria jawaban tinggi, cara meningkatkannya adalah dengan pimpinan lebih sering memberikan arahan kepada pegawai seperti memberi tahu cara melihat kemiripan suatu berkas yang terlihat berbeda. Pada indikator kemampuan pegawai dalam menalar diperoleh nilai rata-rata 3,30dengan kriteria jawaban cukup tinggi, cara meningkatkannya adalah pegawai harus lebih sering bertanya kepada pimpinan dan sesama pegawai dalam hal-hal yang belum dimengerti. Pada indikator kemampuan pegawai mengidentifikasi suatu permasalahan diperoleh nilai rata-rata 3,11 dengan kriteria jawaban cukup tinggi, cara meningkatkannya adalah perusahaan harus lebih sering mengadakan pelatihan untuk pegawainya.

Pada dimensi penalaran deduktif dengan indikator tingkat kelogisan pegawai dalam menilai suatu argumen yang diberikan diperoleh nilai ratarata 3,61 dengan kriteria jawaban tinggi, cara meningkatkannya adalah pegawai harus lebih teliti dan lebih menggunakan logika ketika menilai argumen yang diterimanya. Pada indikator ketelitian pegawai dalam bekerja diperoleh nilai rata-rata 3,30 dengan kriteria jawaban cukup tinggi, cara meningkatkannya adalah perusahaan mengadakan pelatihan-pelatihan untuk meningkatkan ketelitian pegawai dalam bekerja.

Kemampuan intelektual pegawai PT BPRS Amanah Bangsa Pematangsiantar dalam hal ini sudah dikategorikan tinggi. Walaupun sudah dikategorikan tinggi, sebaiknya instansi juga meberikan peluang untuk pendidikan lebih lanjut dan memberikan beasiswa untuk program penyetaraan, memberikan pelatihan secara rutin untuk menggali potensi serta kemampuan pegawai sehingga pegawai memiliki kemahiran dalam menyelesaikan setiap tugasnya.

\section{b. Etos Kerja pada PT BPRS Amanah Bangsa Pematangsiantar}

Etos kerja merupakan seperangkat sikap atau pandangan mendasar yang dipegang pegawai untuk menilai bekerja sebagai suatu hal yang positif bagi penigkatan kualitas kehidupan mereka. Dengan adanya etos kerja dalam diri pegawai, diharapkan akan membuka pandangan dan sikap pegawai untuk menilai tinggi terhadap kerja keras dan sungguhsungguh. Etos kerja yang ada pada PT BPRS Amanah Bangsa Pematangsiantar cukup tinggi, hal ini dapat dilihat dari hasil kuesioner yang dibagikan kepada responden yang secara keseluruhan diperoleh nilai rata-rata 3,37 dengan kriteria jawaban cukup tinggi.

Terdapat beberapa indikator yang masih berada dibawah nilai rata-rata. Seperti pada dimensi kerja adalah rahmat, pada indikator ketulusan dalam bekerja diperoleh nilai rata-rata 3,30 dengan kriteria jawaban cukup tinggi, cara meningkatkannya adalah pegawai harus melatih diri agar lebih tulus dalam bekerja seperti menghilangkan sikap bersungutsungut ketika bekerja. Pada indikator rasa syukur dalam bekerja diperoleh nilai rata-rata 3,26 dengan kriteria jawaban cukup tinggi, cara meningkatkannya adalah pegawai harus melatih diri untuk lebih mensyukuri pekerjaannya seperti menerima dengan senang hati pekerjaannya saat ini hingga timbul keinginan bekerja dengan sungguh-sungguh. Pada indikator kepatuhan dalam bekerja diperoleh nilai rata-rata 3,19 dengan kriteria jawaban cukup tinggi, cara meningkatkannya adalah perusahaan memberikan teguran dan sanksi bagi pegawai yang kurang patuh dalam bekerja.

Pada dimensi kerja adalah aktualisasi, pada indikator keinginan untuk bekerja keras diperoleh nilai rata-rata 3,30 dengan kriteria jawaban cukup tinggi, cara meningkatkannya adalah pegawai harus lebih membiasakan untuk mau bekerja keras dalam pekerjaannya. Pada indikator semangat dalam bekerja diperoleh nilai rata-rata 3,26 dengan kriteria jawaban cukup tinggi, cara meningkatkannya adalah perusahaan memberikan dorongan-dorongan berupa hadiah atau peningkatan karir bagi karyawan yang memiliki semangat yang tinggi dalam bekerja dan melarang pekerja bermain wifi yang tidak ada hubungannya dengan pekerjaan ketika jam kerja. Pada indikator upaya pegawai mendapatkan prestasi diperoleh nilai rata-rata 3,07 dengan kriteria jawaban cukup tinggi, cara meningkatkannya adalah dengan memberikan reward baik langsung dan tidak langsung kepada pegawai yang memiliki prestasi kerja yang inggi.

Pada dimensi kerja adalah ibadah, pada indikator keseriusan pegawai dalam bekerja diperoleh nilai rata-rata 3,23 dengan kriteria jawaban cukup tinggi, cara meningkatkannya adalah dengan memberikan teguran dan sanksi bagi pegawai yang kurang serius dalam bekerja. Pada indikator kecintaan pegawai terhadap pekerjaannya diperoleh nilai rata-rata 3,19 dengan kriteria jawaban cukup tinggi, cara meningkatkannya adalah pegawai harus lebih melatih diri untuk lebih mencintai pekerjaannya dengan melakukan pekerjaan dengan sungguh-sungguh tanpa harus disuruh-suruh atasan. Pada indikator keikhlasan pegawai dalam bekerja diperoleh nilai rata-rata 3,15 dengan kriteria jawaban cukup tinggi, cara meningkatkannya adalah pegawai harus lebih menumbuhkan rasa ikhlas dalam bekerja. Pada dimensi kerja adalah kehormatan, pada indikator tingkat bekerja dengan penuh keunggulan diperoleh nilai rata-rata 3,34 dengan kriteria jawaban cukup tinggi, cara meningkatkannya adalah perusahaan memberikan reward secara langsung ataupun tidak langsung bagi pegawai yang unggul dalam bekerja.

Etos kerja pada PT BPRS Amanah Bangsa Pematangsiantar dalam hal ini dikategorikan cukup baik. Walaupun demikian, perusahaan harus meningkatkan etos kerja bagi para pegawainya dengan lebih memperkuat kerja dengan amanah, panggilan, seni, kehormatan, dan pelayanan agar terciptanya semangat kerja yang lebih tinggi sehingga pegawai dapat lebih memfungsikan etos kerja yang ada dalam dirinya untuk peningkatan kualitas hasil kerja. 


\section{c. Kinerja Pegawai pada PT BPRS Amanah Bangsa Pematangsiantar}

Tinggi rendahnya kinerja karyawan dapat dilihat dari kemampuan karyawan mampu menyelesaikan tugas sehingga mempengaruhi keberhasilan perusahaan itu sendiri. Dimensi kinerja karyawan yang ada pada PT BPRS Amanah Bangsa Pematangsiantar dikatakan sangat tinggi. Hal ini dapat dilihat dari hasil kuesioner yang dibagiikan ke responden, secara keseluruhan dengan nilai sangat tinggi dengan nilai rata-rata 4,06 dengan kriteria jawaban tinggi.

Dari nilai rata-rata diatas ada dimensi kinerja karyawan pada PT BPRS Amanah Bangsa Pematangsiantar yang harus menjadi perhatian yaitu prestasi kerja dan perilaku kerja. Dari perhitungan rata-rata kinerja karyawan diperoleh nilai tinggi, namun ada beberapa aspek dinilai tinggi tetapi nilainya masih dibawah rata-rata dari indikatorindikator lain, yang pertama dimensi prestasi kerja pada indikator terbiasa menyelesaikan tugas dengan mandiri memperoleh nilai sebesar 3,38 dengan kriteria jawaban cukup tinggi. Untuk meningkatkannya karyawan sebaiknya mengukuti pelatihan dengan rutin agar mampu dan terbiasa menyelesaikan tugas dengan mandiri.

Selanjutnya untuk dimensi perilaku kerja pada indikator kreativitas untuk menyelesaikan tugas agar dapat hasil yang baik berada pada nilai rata-rata 4,03 dengan kriteria jawaban tinggi. Hal in disebabkan karena karyawan kurang memiliki kreativitas yang tinggi sebaiknya karyawan lebih sering bertanya dengan karyawan lain tentang tugas sehingga dapat meyelesaikan tugas dengan lebih baik. Pada indikator bertindak sesuai dengan peraturan yang telah ditetapkan memperoleh nilai rata-rata sebesar 3,69 dengan kriteria tinggi. Cara meningkatkannya yaitu sebaiknya karyawan lebih taat lagi dengan peraturan yang telah ditetapkan. Pada indikator bekerja dengan baik dalam tim dipetoleh nilai rata-rata 4,03 dengan kriteria jawaban tinggi, cara meningkatkannya yaitu sebaiknya pegawai lebih berinisiatif dan berkontribusi ketika bekerja dalam tim.

Pada indikator memberikan kontribusi yang baik memperoleh nilai rata-rata sebesar 3,96 dengan kriteria tinggi. Cara meningkatkannya yaitu sebaiknya karyawan saling membantu baik tenaga maupun pikiran saat bekerja dalam tim. Pada indikator tingkat kehadiran memperoleh nilai ratarata 3,76dengan kriteria tinggi. Cara meningkatkannya yaitu karyawan harus lebih disipllin lagi dalam hal kehadiran. Untuk indikator ketepatan waktu atas kehadiran berada pada nilai rata-rata 3,73dengan kriteria tinggi cara untuk meningkatkannya adalah karyawan harus lebih cepat dan tepat waktu datang ke kantor.

Kinerja karyawan pada PT BPRS Amanah Bangsa Pematangsiantar dalam hal ini sudah dikategorikan tinggi. Walaupun dikategorikan tinggi, perusahaan sebaiknya memberikan kesempatan kepada pegawai untuk berinovasi sehingga menimbulkan kreativitas dalam bekerja.

\section{KESIMPULAN DAN SARAN}

1. Kesimpulan

a. Hasil analisis deskriptif kualitatif tentang kemampuan intelektual memiliki nilai ratarata keseluruhan 3,65 dengan kriteria jawaban tinggi. Kemudian nilai rata-rata tertinggi sebesar 4,03 dengan kriteria jawaban tinggi pada pada dimensi ingatan dengan indikator ingatan pegawai dalam mengingat suatu pekerjaan. Sedangkan nilai rata-rata terendah sebesar 3,11 pada dimensi kecepatan konseptual dengan indikator kemampuan pegawai mengidentifikasi perbedaan suatu masalah.

b. Hasil analisis deskriptif kualitatif tentang etos kerja memiliki nilai rata-rata keseluruhan 3,37 dengan kriteria jawaban cukup tinggi. Kemudian nilai rata-rata tertinggi sebesar 3,65 dengan kriteria jawaban tinggi pada dimensi kerja adalah pelayanan dengan indikator bekerja sebagai bentuk pelayanan. Sedangkan nilai rata-rata terendah sebesar 3,15 dengan dimensi kerja adalah ibadah dengan indikator keikhlasan kerja

c. Hasil analisis deskriptif kualitatif tentang kinerja pegawai memiliki nilai rata-rata keseluruhan 4,06 yang berkriteria tinggi. Nilai rata-rata kinerja karyawan tertinggi pada dimensi prestasi kerja dengan indikator mencapai target sesuai dengan waktu yang ditentukan memiliki nilai rata-rata 4,50 yang berkriteria sangat tinggi. Dan nilai rata-rata kinerja karyawan terendah pada dimensi prestasi kerja indikator menyelesaikan tugas dengan memiliki nilai rata-rata 3,38 yang $b$ cukup tinggi.

d. Hasil analisis regresi linear berganda diperoleh persamaan $\hat{\mathrm{Y}}=33,312+0,306 \mathrm{X}_{1}+$ $0,302 \mathrm{X}_{2}$, artinya terdapat pengaruh yang positif antara kemampuan intelektual $\left(\mathrm{X}_{1}\right)$ dan etos kerja $\left(\mathrm{X}_{2}\right)$ terhadap kinerja pegawai $(\mathrm{Y})$ pada PT BPRS Amanah Bangsa Pematangsiantar.

e. Hasil analisis korelasi diperoleh nilai $\mathrm{r}=$ 0,660 , yang artinya terdapat hubungan yang kuat dan positif antara kemampuan intelektual, etos kerja dengan kinerja pegawai pada PT BPRS Amanah Bangsa Pematangsiantar. Sedangkan koefisien determinasi diperoleh nilai $R$ Square sebesar 0,436 , artinya tinggi rendahnya kinerja pegawai sebesar $43,6 \%$ dapat dijelaskan oleh kemampuan intelektual dan etos kerja, sedangkan sisanya sebesar $56,4 \%$ dipengaruhi oleh faktor lain seperti budaya organisasi, motivasi, lingkungan kerja dan lain-lain.

f. Hasil pengujian hipotesis secara simultan (Uji F) diperoleh nilai $F_{\text {hitung }}$ sebesar 8,883 $>F_{\text {tabel }}$ dengan $(0,05 ; 2$ vs 23$)$ sebesar 3,42 atau dengan taraf signifikan $0,000 \leq \alpha 0,05$, maka H0 ditolak, artinya kemampuan intelektual dan etos kerja berpengaruh positif dan 
signifikan terhadap kinerja pegawai PT BPRS Amanah Bangsa Pematangsiantar. Hasil pengujian hipotesis secara parsial (Uji t) diperoleh nilai thitung kemampuan intelektual sebesar 2,298 $>t_{\text {tabel }}$ dengan $\mathrm{df}=\mathrm{n}-\mathrm{k}-1$ (26-2$1=23$ ) sebesar 2,068 atau dengan taraf signifikan $0,031 \leq \alpha \quad 0,05$, maka $\mathrm{H}_{0}$ ditolak, artinya kemampuan intelektual berpengaruh positif dan signifikan terhadap kinerja pegawai pada PT BPRS Amanah Bangsa Pematangsiantar. Kemudian nilai $t_{\text {hitung }}$ pada etos kerja sebesar 3,354 > dari $t_{\text {tabel }}$ dengan $\mathrm{df}=\mathrm{n}-\mathrm{k}-1 \quad(26-2-1=23)$ sebesar 2,068 atau dengan taraf signifikan $0,003 \leq \alpha 0,05$, maka $\mathrm{H}_{0}$ ditolak, artinya etos kerja berpengaruh positif dan signifikan terhadap kinerja pegawai pada PT BPRS Amanah Bangsa Pematangsiantar.

\section{Saran}

a. Kemampuan intelektual pegawai pada PT BPRS Amanah Bangsa Pematangsiantar masih perlu ditingkatkan, untuk itu sebaiknya perusahaan memberikan peluang untuk pendidikan lebih lanjut juga meberika beasiswa untuk program penyetaraan, dan memberikan pelatihan secara rutin untum menggali potensi dan serta kemampuan pegawai sehingga pegawai memiliki kemahiran dalam menyelesaikan setiap tugasnya.

b. Etos kerja pada PT BPRS Amanah Bangsa Pematangsiantar sudah bagus, akan tetapi sebaiknya perusahaan harus meningkatkan etos kerja bagi para pegawainya dengan lebih memperkuat kerja dengan rahmat, panggilan, ibadah, kehormatan, dan pelayanan agar terciptanya semangat kerja yang lebih tinggi sehingga pegawai dapat lebih memfungsikan etos kerja yang ada dalam dirinya untuk peningkatan kualitas hasil kerja.

c. Kinerja karyawan pada PT BPRS Amanah Bangsa Pematangsiantar dalam hal ini sudah dikategorikan sangat tinggi. Walaupun dikategorikan tinggi, sebaiknya perusahaan memberikan kesempatan kepada pegawai untuk berinovasi sehingga menimbulkan kreativitas dalam bekerja.

d. Sehubungan dengan keterbatasan penulis, maka hasil dari penelitian ini masih jauh dari kata sempurna. Untuk itu, penulis menyarankan kepada peneliti selanjutnya agar dapat memasukkan lebih banyak variabel penelitian lain yang tidak dibahas pada penelitian ini, seperti budaya organisasi, motivasi, lingkungan kerja dan lain-lain.

\section{E. DAFTAR PUSTAKA}

Anoraga, Pandji. 2001. Psikologi Kerja.

Jakarta: Penerbit Rineka Cipta.

2009. Manajemen Bisnis. Jakarta:

Rineka Cipta.

Asifudin, Ahmad Janan. 2004. Etos Kerja

Islami. Surakarta:
Cherrington. 2000. Manajemen. Edisi Kedua.

Cetakan Kedelapan belas. Bogor: Grafika Mardi Yuana.

Daft, Richard L. 2002. Manajemen.Edisi Kelima. Jilid I. Jakarta: Erlangga.

Dessler, Gary. 2006. Manajemen Sumber Daya Manusia. Jakarta: Indeks.

Dharma, Agus. 2001. Manajemen Sumber Daya Manusia. Jakarta: Erlangga

Febriana, Puji Maya. 2009. Pengaruh Etos Kerja Islam Terhadap Kinerja Pegawai Pada Bank Pembiayaan Rakyat Syari'ah Artha MasAbadi Kabupaten Pati. Semarang: Institut Agama Islam Negeri Walisongo Semarang. Skripsi

Fitrianto, Rian F. 2011. Pengaruh Etos Kerja Islam Terhadap Kinerja Pegawai

\section{BPRS Buana Mitra}

Perwira Purbalingga. Semarang: Institut Agama Islam Negeri Walisongo Semarang. Skripsi.

Ghozali, Imam. 2016. Aplikasi Analisis Multivariate dengan Program SPSS. Semarang: Penerbit Universitas Diponegoro. Gibson, James, L. 2000. Organisasi, Perilaku, Struktur dan Proses. Edisi V. Cetakan Ketiga. Jakarta: Penerbit Erlangga.

Goleman, Daniel. 2002. Working With

Emotional Intellegence. Jakarta: PT

Gramedia Pustaka Utama.

Griffin, Ricky, W, 2004. Manajemen. Edisi VII, Jilid I. Jakarta: Erlangga.

Haq, Muhibbatul H. 2015. Pengaruh Budaya

Organisasi, Kepemimpinan, Etos

Kerja Islam, Disiplin Kerja, Motivasi,

Kompensasi, Kecerdasan

Emosional dan Kecerdasan

Spiritual Terhadap Kinerja Pegawai

BPRS Yogyakarta. Yogyakarta:

Universitas Islam Negeri Sunan Kalijaga

Yogyakarta. Skripsi.

Luthans, Fred. 2006. Perilaku Organisasi.

Edisi Bahasa Indonesia. Yogyakarta: ANDI.

Mangkunegara, Anwar Prabu. 2004.

Manajemen Sumber Daya Perusahaan. Bandung: PT Remaja Indonesia.

Mangkunegara, Anwar Prabu. 2009. Evaluasi Kinerja Sumber Daya Manusia. Bandung: Refika Aditama.

Mathis, Robert L. Dan John H. Jackson. 2006. Human Resource Managemen. Edisi X. Jakarta: Salemba Empat.

2006. Human Resources

Management. Edisi X. Jakarta: Salemba Empat.

Mondy, Wayne R. 2008. Manajemen Sumber Daya Manusia. Cetakan Kedua. Bogor: Ghalia Indonesia. 
Mubarak, W. 2007. Promosi Kesehatan Sebuah Pengantar Proses

Mengajar Dalam

Belajar

Yogyakarta: Graha Ilmu.

Muda, Iskandar. Ahmad Rafiki. dan Martua Rezeki Harahap. 2014. Factors

influencing employess' performance (a study on the islamic banks in Indonesia). Indonesia: University of North Sumatera, University of Malaysia. Internasional Journal of Business and Social Science. Volume 5, Nomor 2, http://www.ijbssnet.com

Purwanto, Ngalim. 2003. Psikologi

Pendidikan. Bandung: PT Remaja

Rosdakarya.

Rahmad, Nur. 2004. Pengaruh Penematan

Kerja, Lingkungan Kerja,

Komunikasi Kerja Terhadap Kinerja

Pegawai (Studi Kasus Pada

PT

Bank Muamalat Jember). Jember:

Universitas Muhammadiyah. Jurnal Ekonomi. Volume 4, Nomor 2, http://digilib.Unmuhjember.ac.id/download. php?id=2427. 07 Juni 2017.

Rahmatika, Ika. 2014. Pengaruh Kemampuan dan Motivasi Kerja Terhadap Kinerja Pegawai Studi di Bank BNI Syariah Cabang Bogor. Jakarta: UIN Syarief Hidayatullah. Skripsi.

Rivai,Veithzel. 2004. Manajemen Sumber

Daya manusia untuk Perusahaan

dari Teori ke Praktik. Jakarta: PT Raja

Grafindo Persada.

2005. Manajemen Sumber Daya
Manusia untuk Perusahaan

dari

Teori ke

Praktik. Jakarta: PT Raja Grafindo

Persada.

Robbins, Stephen P. 2001. Perilaku

Organisasi. Edisi 8. Jakarta: Prentice

Hall.

Robbins, Stephen P. 2003. Perilaku

Organisasi. Jilid 2. Jakarta: PT Indeks Kelompok Gramedia

Robbins, Stephen P. dan Mary Coulter. 2011.

Manajemen. Edisi Kesepuluh. Jakarta: Erlangga.

Robbins, Stephen P. dan Timothy A. Judge. 2008. Manajemen. Edisi Keduabelas.

Jakarta: Erlangga.

Sinamo. 2005. Delapan Etos Kerja

Profesional: Navigator Anda Menuju Sukses. Bogor: Grafika Mardi Yuana.

Simbolon, Hotman. 2013. Statistika. Yogyakarta: Penerbit Graha Ilmu.

Sugiyono. 2013. Metode Penelitian Kuantitatif Kualitatif dan R\&D. Bandung: Alfabeta.

Surat Edaran Bank Indonesia No. 15/4 Tanggal 26 Februari 2013.

Sutrisno, H. Edy. 2012. Manajem 131 :r Daya Manusia. Edisi Cetakan Ketiga. Jakarta : .......ana.

Tasmara, Toto. 2002. Etos Kerja Islami. Jakarta: Gema Insani Press.

Wibowo. 2007. Manajemen Kinerja. Edisi III. Jakarta: Rajawali Pers. kesembilan. Jilid pertama dan kedua. Jakarta: Prehallindo. 